University of Nebraska - Lincoln

DigitalCommons@University of Nebraska - Lincoln

The Nebraska Educator: A Student-Led Journal Department of Teaching, Learning and Teacher

Education

$10-5-2021$

\title{
Again Awake: A White Researcher's Iterative Positioning for Entering Black Spaces
}

\author{
Eileen Boswell \\ University of Nebraska-Lincoln
}

Follow this and additional works at: https://digitalcommons.unl.edu/nebeducator

Part of the Bilingual, Multilingual, and Multicultural Education Commons, and the Other Social and Behavioral Sciences Commons

Boswell, Eileen, "Again Awake: A White Researcher's Iterative Positioning for Entering Black Spaces" (2021). The Nebraska Educator: A Student-Led Journal. 59.

https://digitalcommons.unl.edu/nebeducator/59

This Article is brought to you for free and open access by the Department of Teaching, Learning and Teacher Education at DigitalCommons@University of Nebraska - Lincoln. It has been accepted for inclusion in The Nebraska Educator: A Student-Led Journal by an authorized administrator of DigitalCommons@University of Nebraska - Lincoln. 


\title{
Again Awake: A White Researcher's Iterative Positioning for Entering Black Spaces
}

\author{
Eileen Boswell \\ Department of Teaching, Learning, and Teacher Education \\ University of Nebraska-Lincoln
}

\begin{abstract}
In this blend of critical annotation and personal reflection, the author narratively frames a selection of works comprising a contextualized reading list for White researchers confronting and positioning their whiteness for the first time. Built around 21 influential texts, this personalized collection of what to read and possible directions for contemplation reflects one educator's awakening to the crucial situating of White research in Black spaces. The texts include academic journal articles, magazine pieces, and book chapters covering topical and methodological considerations, in addition to monographs and popular press books. The narrative and annotation are interwoven, creating a mini literature review that is grounded in the author's iterative forays into research with Black students as her own awareness of race as a power construct (Kendi, 2019) and of her whiteness are continually challenged and developed through classroom, community, and campus experiences. This iterative process is necessary and natural, but requires a zigging and zagging of racial consciousness for which semester-length course models and individual books do not automatically provide adequate guidance. The intended audience for this paper is any graduate student or professional researcher who is taking on not only the steep climb of antiracist activism out in the world, but also the internal, sincere, and cyclical self-education that comes with authentic racial awakening.
\end{abstract}

Keywords: researcher positionality and reflexivity, critical race theory, critical Black

studies, critical whiteness studies, racial capitalism

\section{Author Note}

Thank you to Zac Casey, Amanda Morales, and the staff and reviewers of this journal for supporting this work throughout multiple reformulations. 


\section{THE NEBRASKA EDUCATOR, VOLUME 6}

In every story, every secret told, you are not the first to wake up - to learn your lines before you have the part.

-Carl Newman, Unguided 


\section{THE NEBRASKA EDUCATOR, VOLUME 6}

About fifteen years ago, at a late spring potluck dinner in my apartment complex, a friend of a friend of mine named Helen announced she was taking a class through her church about race. I didn't know Helen well; mostly we were joined through mutual friends and saw each other at their home only occasionally. But Helen had announced in an around-the-room say-onething-about-yourself ice-breaker that she was taking this race class. That was 2006. I've lost track of Helen, and of our mutual friends for that matter, but still it sticks with me that Helen, who is light-skinned, shared this with a group of almost-strangers who stared awkwardly at their paper plates as she made this disclosure.

Fast forward to 2015 when $\mathrm{I}^{5}$ was taking an improv class at the Omaha Community Playhouse. In one exercise, the instructions were to line up single file, then quickly answer a 'deep' question from the improv player in front of you in line, and then immediately turn around and ask a new deep question to the person behind you. I can't remember what the person in front of me asked, but after I answered and swung around, I said to the player behind me, "What are you afraid of?" I asked this enthusiastically, in keeping with the improv instructor's directives. Recalling this incident today, I distinctly remember that the person behind me replied nonchalantly, "White people." At that moment I had what I now know to call a flash of fragility, although I was far from knowing this term at the time.

Touchstone moments such as these, as well as the physical objects that accompany themthe tattered prompt cards at improv, the soggy paper plates at the potluck—stand as signifiers of my racial ignorance and of its slow disassembly. Along the way, these moments are punctuated by the texts I was reading as I gradually came face to face with my own racial socialization, both privately and in interactions for which I had varying levels of preparation (or grace). This paper

\footnotetext{
${ }^{5}$ First person is used throughout, where appropriate, in keeping with the emphasis on reflexivity and positionality.
} 


\section{THE NEBRASKA EDUCATOR, VOLUME 6}

reconfigures a critical annotation I wrote when I was beginning to confront my White socialization as a person, educator, and researcher. The principal aim of this collection is to articulate my understanding of race as a social power construct (Kendi, 2019). I further aim to summarize the key resources that have begun to weave together into my understanding of the modern-day manifestations of the U. S. history of racial capitalism. I begin with a set of annotations that informs my positionality as a White researcher working with Black students as participants in my dissertation project. Then I cover texts concerning the origins of racial categorization in the United States, followed by contemporary critical race studies. I close with seminal works of Black and African studies. All 21 texts annotated herein appear as a list in Appendix A.

\section{Conceptual Framework}

I am an 'educated' person by many metrics. Nevertheless, I was 41 and in a doctoral program before I deeply and directly confronted issues of race-in my upbringing, in my chosen field, and in myself. So it is that when asked to craft a critical annotation on race for a class project, I chose to write about my "White awakening" — a rude one at that — and how it shapes my work as a teacher educator, education researcher, citizen, and human. Doing race work is a constant collision of what I know and what I don't know, personally and professionally. I would also describe my White racial awakening this way. In the sections that follow, I imagine this process as a series of four 90-degree turns, or "reflective pivots" that lead me through a full circle of critical contemplation. As depicted in Figure 1 below, I use four lenses to approach my White awakening; each of these lenses corresponds to one of the four turns or pivots, and each pivot corresponds a cluster of texts on a particular topic that has been indispensable to my continued racial awakening. 
THE NEBRASKA EDUCATOR, VOLUME 6

\section{Figure 1.}

Conceptual Framework: Four Lens/Reflective Pivots

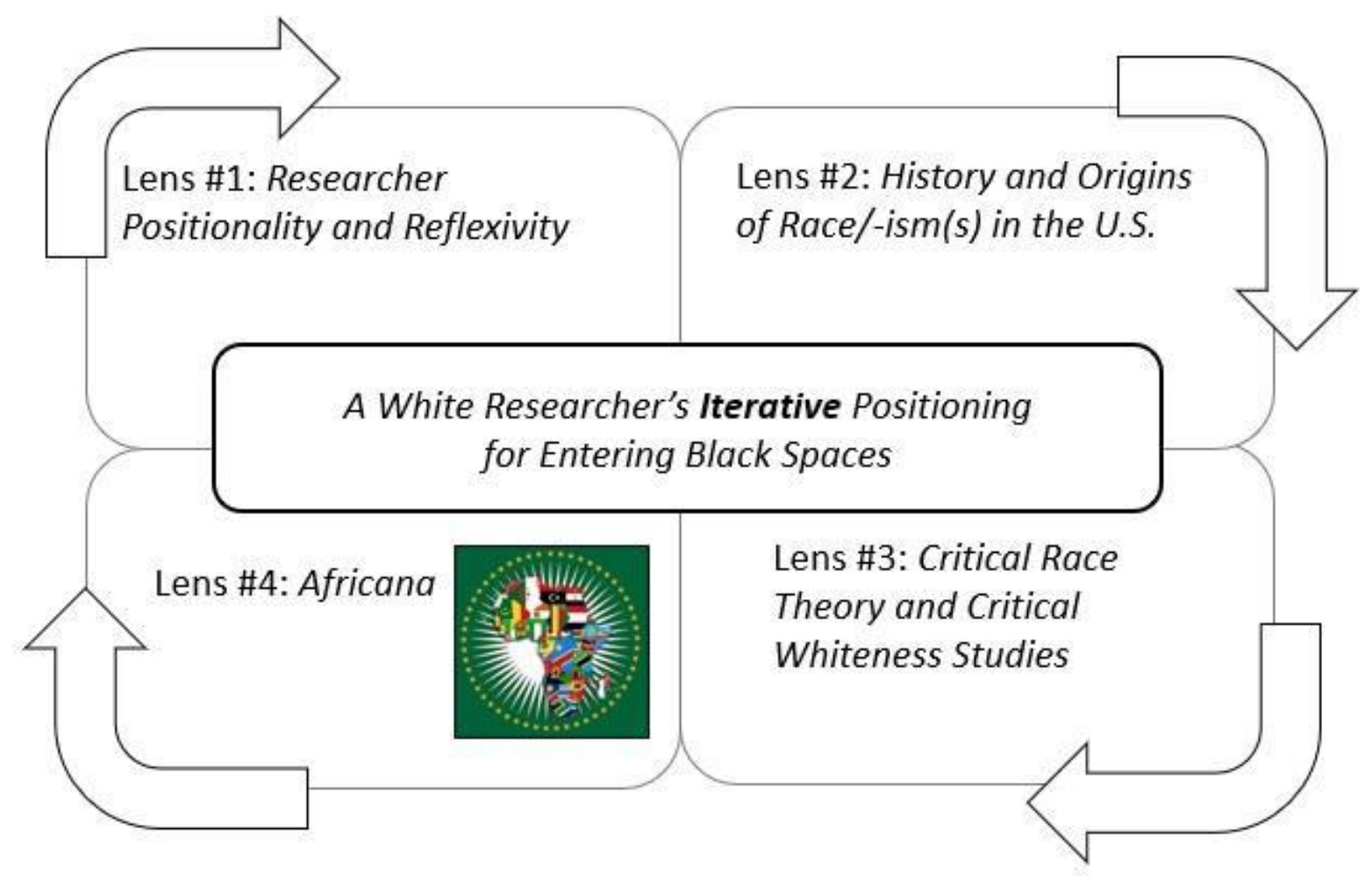

The four lenses or text clusters that guide my continued racial awakening are: (1) qualitative research methodology that specifically attends to researcher positionality and reflexivity; (2) works explaining the origins of race and racism in the United States; (3) critical race theory and other criticalities; and (4) works of Africana, including those that teach about Afro-centric curricula. Following a brief anecdote - as this is an annotation wrapped in a narrative, or perhaps the other way round - the paper describes the most important readings that have helped me understand racial socialization and my own social location, the critical studies that provide me with specific nomenclature and tenets to continue studying race critically, as 
THE NEBRASKA EDUCATOR, VOLUME 6

well as practical applications of these theoretical frameworks to research, pedagogy, and my ongoing personal and professional work.

\section{The Incident of the Fine-Toothed Comb}

I once heard that the secret to writing a compelling screenplay is that viewers must feel they have entered the middle of the story, not the beginning. This is the middle of my story. I'm standing in my classroom trying to build rapport and orient my undergraduate students at the beginning of the semester. The orientation part asks them to complete a syllabus quiz, which in turn asks them to "go through the syllabus with a fine-toothed comb." Without skipping a beat, I add, "I'll supply the comb" with what I think is wry wit as I circulate throughout the room handing out plastic combs I bought at CVS on my way to campus. (I had a self-congratulatory chuckle thinking of this joke while in transit.) After depositing three or four of these cheap plastic objects on each team's table, it suddenly dawns on me that the comb I am brandishing is a White person's comb. This is just one of the spontaneous awakenings I have had to my whiteness and how it figures into my behavior in a room where students of color are also present. In the sections that follow I will revisit the idea that a physical object, such as the comb, can stand as an artifact of racial awakening, and I am grateful for these tactile reminders of my White racial socialization.

"Wisdom often arrives as a warning" said poet Ocean Vuong (Tippett, 2020), and this incident was a warning to me that I need to WAKE UP if I plan to continue educating myself and others. As I position myself, reposition myself, and acknowledge my whiteness in different spaces, I sometimes feel, as Newman (2007) wrote, that I am 'learning my lines before I have the part.' I experience this acute dimension of antiracism as though I were an impostor-a racist masquerading as an antiracist. There have been times in this process when I did not know what 


\section{THE NEBRASKA EDUCATOR, VOLUME 6}

to say, but there have also been times when I had the words but didn't quite feel that I 'had the part' of speaking as an antiracist. These ideas of knowing and not knowing what to say, and having and not having a role to play are iteratively part of positioning myself in all my teaching and research, which, of course, entails live human interactions with other people-encounters for which we must genuinely prepare and for which we are never totally prepared either.

The textual experiences that hew this process are as important as the non-text experiences, such as the fine-toothed comb incident, because a racial reckoning can never be only an academic exercise. My commitment to this dual process — awakening through quotidian moments alongside the heavy lifting of academic study—is informed by work on intertextuality. Readers can think of the works in this annotation as being, in Sarroub's (2005) words, "forms of discourse that were manifested in different contexts and that bridge, subvert, and recreate" (p. 60). Sarroub draws on Gee's $(2004,2015)$ work in discourse analysis, as well as Erving Goffman's (1959) work, and stresses how these theorists teach us that "the presentation of self and identity [are] relational activities whose textual performance is mediated by the space that participants occupy" (Sarroub, 2005, p. 60). Therefore, as I annotate below the works that have facilitated my iterative awakenings, I challenge the reader to imagine an everyday object (perhaps a piece of cotton clothing, which calls to mind the enslavement of Africans on U.S. cotton plantations) or an encounter that brings each text to life in the course of our collective antiracist work. This can be a disturbing activity—and necessarily so — as it disrupts complacency and unearned comfort with whiteness and how it has been constructed through the othering of communities of color. As Lensmire (2017) has written, “as white people, we used people of color to figure out who we were. We used, and continue to use, people of color to 
THE NEBRASKA EDUCATOR, VOLUME 6

create ourselves as white Americans" (p. 7). In the following section I explore how this has operated in my own presentation of self and identity.

\section{Pivot 1: Know Thyself}

\section{Positioning Myself in this Paper and Beyond}

I identify as privileged, Euro-American and in middle age, reared and socialized as "White" in a Catholic, middle-class household in the midwestern region of the United States. Anti-Latinx racism, subtle and overt, was common in my childhood community. My exposure to, and socialization around, Black individuals was different and more complex. I had regular contact with African Americans but not in contexts where we would ever be friends or put into meaningful dialogue with each other. Moreover, Black Americans who had moved to the United States from African countries or from Haiti (I knew both in my small town) were characterized differently from those born in this country: I began to understand that people labeled as 'immigrants' or 'refugees' were treated differently from those visiting short-term, with prestige placed on all things 'international.' I had met a number of people born in Africa before I traveled there myself ${ }^{6}$ and chose to engage in research projects alongside African-born students and families who have immigrated to the United States.

I was socialized to help, but not to understand or learn from, individuals and groups portrayed as other in relation to my birth family, congregation, and the predominantly White community that contained and constrained all of my social, academic, and religious education. As I am now in direct engagement with students of color, it is paramount that I continually reposition myself, using the lenses and reflective pivots described herein, in order to mitigate bias and build trustworthiness with my participants. But for all of us, standing in a classroom or

\footnotetext{
${ }^{6}$ I lived in Senegal and Guinea, West Africa, from 1998 to 2001 as a teaching volunteer for a U.S.-government sponsored service program.
} 
THE NEBRASKA EDUCATOR, VOLUME 6

research space with any students of color requires an acknowledgment of how we are all raced, classed, gendered, as well as how we are alternately othered or cast as main players in the dominant narrative. Some of the methodological literature guiding qualitative researchers aids in this process.

\section{Positionality and Reflexivity in Qualitative Methodology}

Reflexivity is the process of "researching the self, researching the self in relation to others, engaged reflection and representation, and shifting from the self to system" (Milner, 2007, p. 388). It involves seeking "heightened awareness of the self in the process of knowledge creation, a clarification of how one's beliefs have been socially constructed" (Grbich, 2013, p. 113). Positionality, or "positioning" oneself, is about power; it requires "thinking about the ways in which our social positions influence not only our interactions in the field but also what we see and hear" (Reyes, 2017, p. 212) as well as "the realization that who we are as people interplays with how we conduct research" (Ardoin \& martinez, 2019, p. 6). Positionality extends to the researcher-participant dynamic as well—one that is all too often "characterized by the 'powerful' researcher and the 'meek' respondent" (Hoong Sin, 2007, p. 478). Qualitative research reports often include an author positionality statement; sample positionality statements appear above (mine) and are linked in footnote 2 of Appendix B.

Although they may be lacking from quantitative research, positionality and reflexivity form a "qualitative imperative" (Boswell, 2021) in naturalistic inquiry. Often when this imperative is undertaken in qualitative research, the author(s) of a study might consider the "usual suspects" of race, class, and gender-all of which could be crucial elements of positionality. But depending on the focus of the study, additional elements to consider could include the researcher's age, ability, immigration or citizenship status, military/veteran status, 


\section{THE NEBRASKA EDUCATOR, VOLUME 6}

caste, religion, educations, experience, and housing/mobility or incarceration status. Education researchers new to reflexivity and positionality can glean helpful details about how to approach these topics by studying Roni Berger's work. Berger (2015) is a grief researcher who deeply considers the implications of one's insider/outsider status in the field, writing that, "The degree of researcher's personal familiarity with the experience of participants potentially impacts all phases of the research process, including recruitment of participants, collecting data via interviews and/or observations, analyzing and making meaning of the data, and drawing conclusions" (Berger, 2015, p. 229, sic). Importantly, one's position in relation to the research can be additive and not just subtractive, in that it can confer additional dimensions of insight and empathy.

Tying these frameworks back to my own research, I acknowledge that my research with Black students will not be free of bias, but its biases can be managed by taking all of the above into account. My own beliefs and biases motivate, shape, and limit my research. Given this handicap, I have chosen Richard Milner's (2007) work on race, culture, and positionality to lead myself through considering how my research approach can be meaningfully and sensitively improved by committing to a rigorous de-centering of my power as a White person. Being mindful of this downshift aids in preventing the known dangers of patriarchal approaches to education research including framing a study on students of color with race-blind, color-blind, or culture-blind assumptions (Milner, 2007, p. 392). I am, inescapably, a White researcher inserting myself in Black communities for research purposes, and increased reflection will not alter this reality. I will perpetually need to subordinate myself in relation to my research participants and thus, keeping Milner's prescriptions and proscriptions top of mind. 
THE NEBRASKA EDUCATOR, VOLUME 6

\section{Reflecting On, and Positioning, Our Institutions}

Personal reflexivity can be augmented by considering institutional positionality, or the ways in which one's institutional histories and affiliations direct one's research. Leigh Patel's (2016) Decolonizing Educational Research ought to be required reading for graduate students earning advanced degrees in education at any institution voicing a commitment to antiracism, social justice, or dismantling White supremacy as embodied in institutions of higher learning. To begin, Patel establishes what is meant by settler colonial "logics" and how they are enacted in higher education, and especially in education research. Deficit perspectives in education, Patel argues, are enacted by "a seemingly endless stream of interventions for 'at-risk' populations" (p. 26). In this way, "[E]ducational research is complicit in a system that normalizes the achievement and wealth of some while pathologizing and marginalizing others" (p. 21). In the second chapter, Patel builds from these premises to critique "the academy's closed circuitry of publication" (p. 44), pointing out ideological flaws with formulaic approaches to dissertation research that confer all-knowing status to the researcher at the expense of authenticity with participants. "The role of the researcher as detector and implicit fixer or resolver of pathologies" they write, "also subtly imbues the researcher with an almost omniscient-like ability to know" (p. 41). They call on education researchers to be more intentional and explicit about how scholarly work is situated in and affected by material conditions and ideologies (p. 66) as well as to recognize how specialization silos give us permission to ignore, and thus perpetuate, settler colonial logics in the academy.

Patel asserts that "research is relational" (p. 48) and demonstrates how education research reifies colonial and imperial systems of power and dominance, underscoring that, "Logics of coloniality are problematically enlivened through educational research" and that "[e]ducational 
THE NEBRASKA EDUCATOR, VOLUME 6

research is a text, and as such, is never neutral but instead imbricated with potential and unruliness to motivate, disincentivize, and render invisible various realities" (Patel, 2015, pp. 12-13). Part of viewing the university as an institution as susceptible to - and guilty ofinstitutional racism as any government agency or corporation is understanding how the different levels of racism in our society interlock. To this point, Scheurich and Young (1997) delineate distinct levels of racism from individual to civilizational. Their construct of epistemological racism, for example, exists at the civilizational level (p. 4). Epistemological racism is a structured and entrenched form of racism whereby some ways of knowing are legitimated at the expense of others. This leads to the domination of academic publishing by work exhibiting predominantly White, masculinist, Eurocentric ideologies.

Monopolies of thought, as described in theories of epistemological racism, are further delineated by Kubota (2020), who alerts us that even an author's name can dissuade publishers from choosing to advance a manuscript if the name is indicative of a particular race, gender, or other identity. Kubota emphasizes that, "the perceived legitimacy of knowledge is linked to the location of knowledge production" (p. 721). Their call to action includes denouncing the system that has resulted in near worship of European and North American (the "Global North") knowledge systems, which reproduce themselves in academic publishing without a sustained disruption of the systems that legitimate and publish only certain knowledges. This disruption relies upon courageous scholars of color and their White colleagues to bring attention to oppressive research and publishing practices akin to what Kubota highlights. Calling out institutional racism ultimately leads us to ask how we got here. 
THE NEBRASKA EDUCATOR, VOLUME 6

\section{Pivot 2: Origins of Racial Categorization}

In the opening to A Pedagogy of Anticapitalist Antiracism: Whiteness, Neoliberalism, and Resistance in Education, Zac Casey (2016) writes, "I am not here, in the United States as a white man, by chance or accident. People killed other people so that I could live here" (p. 7). When I first read this, it called to mind another physical object that serves as a touchstone of my racial awakening - a felt Halloween costume (hand-sewn by my mother) I had worn in my youth, one that remade my appearance into that of a Native woman. We would have unthinkingly called this an 'Indian' costume with zero awareness of what this act of costuming meant or harkened to. I remember the fringe at the bottom and the feathers on top: a sensory experience devoid of any understanding of Native peoples or why it was considered socially acceptable for me to walk the streets dressed as one of them on this one day of the year. Native dress was a contrastive 'costume' with my regular clothes and school uniform because I was 'White'...even if this truth was never uttered aloud.

\section{How Did I Become White?}

The Halloween costume as a bodily experience, coupled with text experiences as I began to read poetry, are obvolute in my racial socialization. I, along with other U.S.-born people, first encountered Ralph Waldo Emerson as a poet and essayist, and an oft-quoted wordsmith who delivered inspirational adages. Indeed, I probably had more than a few bookmarks, calendars and coffee cups with Emerson quotes on them. Over the past two years, though, Nell Irvin Painter's (2010) The History of White People has had me questioning what it meant for me to use a bookmark or coffee cup bearing a celebrated quote from an early U.S. citizen who is roundly revered in many literary and political circles, but who has now come to be seen as a 'founding father' of White supremacist notions. I selected Painter's book for this collection because 


\section{THE NEBRASKA EDUCATOR, VOLUME 6}

learning more about who has been written into and out of history scrambles my ideas of who is an 'American hero.' Thomas Jefferson, for example, Emerson, and others, come under scrutiny in Painter's book for their contributions to White racial ideals in the early United States. Painter devotes an entire chapter to Emerson and his work on what later came to be known as English traits.

Painter's book is particularly important to me in reinterpreting my upbringing as the grandchild of Hungarian, Polish, and Irish immigrants to the United States. Traces of Painter's argument are evidenced in stereotypes I overheard while growing up. One whole chapter of Painter's book details comparisons made between Black Africans/African Americans/West Indians and the Irish, who were collectively essentialized in cartoons and pervasive jokes as backward, dirty, impure, and incapable of governing themselves (pp. 132-150). Studying this aspect of history and the story of How the Irish Became White, I was horrified to learn of efforts to dissuade Irish immigrants from joining the Abolitionist movement in the first half of the nineteenth century (Ignatiev, 2009, pp. 20-26).

The primary role of Painter's text in my racial awakening is that it details the historical power dynamics whereby arbitrary genetic differences were repackaged by the ruling class as desirable qualities, despite the fact that they are largely cosmetic differences outside human control. Painter's book shows convincingly that differences can be manipulated to dehumanize,

to divide, and to conquer. The more arbitrary and involuntary the difference, the more a powerful ruling majority can exploit it for their personal gain. This kernel of an idea-that difference started out as arbitrary but was refashioned into something thought to be permanent and meaningful—sits at the base of my understanding of race and racialization. 
THE NEBRASKA EDUCATOR, VOLUME 6

\section{American Slavery and Racial Capitalism ${ }^{7}$}

There is an anecdote that appears in Isabel Wilkerson's (2020) Caste in which someone approaches Wilkerson after a lecture and says, "There are no Black people in Africa” (p. 52). This sentence is used to upend the way many people came to think about race. Africans, as it were, became 'Black' once enslaved, just as the Irish became White once enlisted in bigotry against Black Americans. Coates (2015) has expressed this sentiment by saying that, "race is the child of racism, not the father" (p. 7). It was, in other words, colonial power structures that imbued color differences with social significance and not something inherent in the differences themselves. Processing this reversal of what I had long (mis)understood about my social studies education in high school, I progressed from Nell Painter's work to scholarship on racial capitalism that revealed to me the economic motivations and pervasive greed that led to the system of racial capitalism that persists in the United States today.

Racial capitalism is the hierarchical categorization of human beings for economic purposes - an historical fact that was instrumental in the creation of the early United States of America, prior to independence. The specific histories of racial categorization and racial socialization must inform the analysis of any legacic colonization experiences. Indeed, Ribeiro (2011) emphasizes that a focus on capitalism, the driver of slavery and thence anti-Black racism in this country, must be "the primordial focus of analysis" (p. 290) in any approach to studying post-, neo-, or other colonialisms. Thus, the conceptual underpinnings of racial capitalism begin with the theory that capitalist-centered greed and self-interest led to slavery in the early United States as a means of using exploited African labor to work on land seized through the genocide and exploitation of Indigenous American peoples of many tribal affiliations and heritages.

\footnotetext{
${ }^{7}$ Additional information about racial capitalism appears in the Critical Black Studies section.
} 


\section{THE NEBRASKA EDUCATOR, VOLUME 6}

The provenance of the term racial capitalism is a White, Marxist publication from an economic group in London (Legassick \& Hemson, 1976) during anti-apartheid movements that mobilized activists in the United Kingdom, the United States, and across the globe in support of South African liberation leaders. While the term and its use were contested within and across various anti-apartheid movements, the circulation of the term reached a critical mass and in 1979 Neville Alexander — a leader of the black consciousness movement in South Africa—introduced the term into the rhetoric of South African liberation struggles. Four years later, Alexander had fully adopted a theory of racial capitalism as espoused in his 1983 national forum committee speech on the fitness of a theory of racial capitalism to oppose 'non-racialism' (i.e., colorblind) ideologies. Johnson $(2009,2013,2018)$ and Baptist (2016) extend this history to show that, although slavery pre-dated the colonization of what is now the United States, the use of enslaved labor to facilitate economic advance on a massive scale is a uniquely American invention.

Exposing the horrors of history points to the ways in which economics and racial dynamics are inextricably entwined in the United States. Additional research has focused on the role of racial capitalism and slavery in building some of today's most prestigious institutions of higher learning (Wilder, 2014). To begin to unravel these dynamics, Golash-Boza (2016) explains the historical construction of race and its ties to multiple forms of subjugation, stating that, "Europeans and their descendants have used the idea of race to rationalize exploitation, slavery, colonialism, and genocide" (p. 4). The colonizers' ideologies of social superiority created a race-based system of hierarchy that relegated African people to the lowest rungs of society. 
THE NEBRASKA EDUCATOR, VOLUME 6

\section{What is Race?}

Golash-Boza's (2016) Race \& Racisms: A Critical Approach provides an unambiguous historical record of how race has been socially constructed and used as a justification for sociopolitical systems including apartheid, slavery, and other forms of torture. Its introductory chapter sits in sharp relief to the 1980s schooling I encountered with regard to Christopher Columbus and the 'discovery' of America. Connecting historical conceptions of race to present day conditions in the United States, Golash-Boza's work, as well as Omi and Winant's (2014) Racial Formations in the United States refute biological or scientific bases of race and argue instead that race is a political invention to preserve the self-interest of those in power. After establishing the facts in this regard, and contextualizing them against the United States' troubled history of race-based policies, Omi and Winant forge a new definition of race: "an unstable and 'decentered' complex of social meanings constantly being transformed by political struggle” (p. 7). It is with this definition that I pivot to scholarly pieces that structure my developing knowledge of race-based theories and epistemologies.

\section{Pivot 3: Critical Race Studies}

\section{Critical Race Theory}

I had difficulty at first understanding the widespread effects of White dominance in education and industry. For me, keeping in mind the image of a "flesh-colored" Crayon or BandAid was one way to examine how commonplace the idea of whiteness as default or whiteness as 'normal' pervaded my adolescence. These objects are the visual framing that I use to guide my study of systemic racism and White supremacy, as outlined below. 
THE NEBRASKA EDUCATOR, VOLUME 6

\section{Key Tenets}

Before celebrating key texts in critical race theory (CRT), I first briefly explain seven key tenets of CRT that guide my work:

1. Racism is ordinary (Delgado \& Stefancic, 2017, p.8); one need not create any conditions to find it because it is embedded into U.S. social dynamics. In other words, "The system isn't broken; it was built this way."

2. Whiteness is a form of 'property' or capital that confers upon its members certain unearned advantages.

3. So-called 'colorblindness' or race-neutral policies and practices do not liberate communities of color and in fact will inevitably sustain advantages for the dominant race (i.e., White individuals) who already enjoy these unearned advantages.

4. Whiteness and White people must be de-centered in discussions of race because claiming a White person's views on the matter are' objective', 'neutral', or 'normative' erases the centrality of other people's authoritative knowledge about their own experiences of oppression. The knowledge and experiences of Black, Indigenous, and people of color must be centered in the study of racial dynamics - a principle sometimes called the centrality of experiential knowledge (Pérez Huber, 2009).

5. Intersectionality (Crenshaw, 1990, 1997, 2017; Hill Collins \& Bilge, 2020) is the notion that overlapping identities create unique circumstances of oppression that cannot be fully understood (or remedied in the law) by an additive view of multiple identities, such as being a person of color living with a disability.

6. Interest convergence (Bell Jr, 1980), whereby the interests of those in power occasionally converge with the advancement of communities of color, is commonplace. White people 
THE NEBRASKA EDUCATOR, VOLUME 6

confer such advancements in due time that our own interests converge. There is also a companion principle of interest divergence.

7. Material aims refers to the fact that communities of color and Indigenous populations have endured material losses perpetrated in the pursuit of establishing and maintaining racial hierarchies. There is thus a concurrent principle of pursuing material changes and palpable gains for those who have been oppressed.

\section{Key Resources}

While there are far too many resources on writ large to include herein, a few stand out as forming the foundation to which I return often in order to re-explain CRT to myself and to find simplified ways to explain it to others. Published more than twenty years apart, Ladson-Billings and Tate's (1995) call for a critical race theory of education and Delgado and Stefancic's (2017) more recent primer on the same topic give any student a concise set of talking points and rationale for CRT and its application to the field of education. Noteworthy is Ladson-Billings and Tate's argument that racial inequities in education are not surprising and in fact they are a "logical and predictable result" (p. 47) of not attending to the racialized dimensions of our society and our public institutions. The authors recommend that one must not assume a bland, inconsequential "unity of difference" but rather that race must be the central concern of renewed curriculum efforts (Ladson-Billings \& Tate, 1995, p. 62). This brings us to critical pedagogy and the first of several scholars whose work highlights the subjugation embedded in normative (i.e., White, Euro-American, masculinist) curricula.

\section{Critical Pedagogy}

Critical pedagogy interrogates not only how we teach but what concepts we take for granted. In their chapter on Dissonance, Taylor and Reynolds (2019) recount their experiences as 


\section{THE NEBRASKA EDUCATOR, VOLUME 6}

two participants on a service-learning trip focused on school improvement in Ecuador. Their thesis is that such trips, designed as they are to enlighten college students to the plight of those "less fortunate," are themselves created around White, masculinist, Eurocentric epistemologies. Using a Black feminist framework, they go on to point out the limitations of the "foundational conceptualizations of dissonance" and then propose their "critical conceptualizations of dissonance" (Taylor \& Reynolds, 2019, pp. 98-100). The differences between the two models begin with the premise that women and people of color have experienced doubt more often than not as the target of White, masculinist bias, skepticism, and speculation; therefore, relying on a 1950s definition of dissonance steeped in an individual's otherwise blissfully ignorant view of the world is misapplied if used in educational contexts where learners of color are present.

Even as a pedagogically useful concept, cognitive dissonance and its associated educational theories the authors argue, "stemmed from positions of unexamined privilege and thus are often inaccurate given that they do not account for students' lived experiences amid societal systems of privilege and oppression" (Taylor \& Reynolds, 2019, p. 94). Their redefinition of dissonance upends the foundational conceptualizations by incorporating lies into the bedrock experience of students of color - thereby clarifying that the racial discrimination experienced by minority members of a service-learning group can be so oppressive as to impede learning. Thus, they help us see that not all dissonance is productive and that if oppressive dissonance cannot be resolved it then has to be met with support and solidarity (Taylor \& Reynolds, 2019, p. 100) if learning is to occur.

Taylor and Reynolds's redefinition is an unequivocal challenge to a very popular concept. In articulating this challenge, they confront the status quo and broaden our fundamental concepts to better represent students and citizens through their deft application of pluralist and 
THE NEBRASKA EDUCATOR, VOLUME 6

critical frameworks. Another disruption of the status quo comes from Picower (2009) who grounds a theory of the "tools of Whiteness" pre-service teachers exhibit when confronted with racial inequalities in education. Emotional, ideological, and performative ways of deflecting and rationalizing White privilege, as well as reverse (i.e., White) victimization comprise these tools. Disabling these tools cannot exclusively be handled by centering concepts of privilege (Lensmire et al., 2013; Leonardo, 2004); it requires large-scale efforts to diversify teachers and curriculum, collaborate with awakened and awakening White educators, as well as meaningfully involving community stakeholders outside of the academy.

Within the academy there is also work to be done. Jupp, Berry, Morales, and Mason (2018) caution teacher educators to not only develop critical and decolonizing education sciences but to utilize them to respond to the ubiquitous demands of (White) institutional practices in teacher education through clear historical contextualization of the tools of critical pedagogy. In so doing, they argue, critical pedagogy can "spurn previous education science's Eurocentric, whitened, and universal aspirations" (Jupp, Berry, Morales, \& Mason, 2018, p. 306).

\section{Critical Whiteness Studies}

Jupp (2020) traces the history of critical White studies (CWS), a term used interchangeably with critical whiteness studies (p. 1). CWS is crucial in teacher education and education research because it rightly labels whiteness as hegemonic normativity; condemns uncritical notions of White identity and nation building; and incorporates CRT's principles of whiteness as property, unwarranted White privilege, and racism made manifest through falsely neutral notions of colorblindness or race-evasion (Jupp, 2020 p. 4).

In my current research I use a CWS lens to craft appropriate positioning and humility for my dissertation examining the racialized campus experiences of Black, African students at 
THE NEBRASKA EDUCATOR, VOLUME 6

predominantly White institutions. Given that I taught in some of the same postcolonial African countries whence come these students (and consequently believed, erroneously, that I understood something about race), I draw on CWS to humble myself to the legacy of White domination of Black communities. Toward this aim, Ribeiro (2011) suggests that "what is needed is a postimperial imagination, critique, and programme" (p. 295). I therefore focus on inverting the 'America-first' motives that drove me_as a U.S.-government sponsored volunteer boasting diplomatic protections and having sworn an oath to the U.S. Constitution - to West Africa in order to teach people there particular competencies their government and my own had determined to be important life skills. Twenty years later, I am now painfully and painstakingly reassessing the impact of my presence as a 'teacher' in the village that hosted me, alongside the propagandist narrative that I was serving people who needed something for me. Whereas I am loath to claim that my dissertation work constitutes a reversal of those actions, the project is an inversion of the colonizing drive that sent me to West Africa. It is thusly that I pivot at this juncture from critical White studies to critical Black studies, and to adjacent works of Africana.

\section{Pivot 4: Africana and Critical Black Studies}

The reflective pivot to Africana is necessary in order for me to contemplate what it meant for me to be White in West Africa and what it now means for me to be White in Nebraska, and how these racialized experiences interrelate. Doing so requires that I supplement my previous travel and service experiences with academic and historic texts pertaining to the transatlantic slave trade and the resulting African diaspora in North America.

\section{Back to Africa}

To tie the historical status of African Americans to the continent of Africa and the panAfrican movements for Black liberation, one can look to Marcus Garvey. Garvey led the 
THE NEBRASKA EDUCATOR, VOLUME 6

Universal Negro Improvement Association (UNIA), sometimes referred to as the "Back to Africa" movement, owing to its call for an "autonomous, black-led nation" on the African continent (Garvey, 1920, p. 1). The UNIA creed enumerating the rights of African American veterans of World War I and their disillusioned Black compatriots was entitled the Declaration of the Rights of the Negro Peoples of the World and has special significance for me as I seek to integrate my knowledge of and experiences in Africa (and with Africans) with my experience as a White U.S. American among African Americans.

Garvey astutely echoes the Declaration of Independence in noting that "all men are created equal" ( $\S$ II.1) despite the discriminatory treatment of war-weary returning Black soldiers at the time. Labor, taxation, terminology, and torture are among the issues addressed in Garvey's Declaration. This is an essential piece for students to contemplate historical systems of power, and race-based rights for Black individuals, and then to question this and grieve the realization that some American citizens have race-based rights conferred through our White skin as a birthright. What Garvey is arguing for is what many of us inherited and will unwittingly pass on.

\section{Critical Black Studies}

A central work in critical Black studies — one that belongs here as well as in the Critical Race Studies section above, is Cedric Robinson's (2020) Black Marxism: The Making of the

\section{Black Radical Tradition}

While the South African liberation movement was popularizing the phrase "racial capitalism" in the 1970s and '80s, Robinson was a student at Berkeley, following the antiapartheid movement from California while studying Indigenous communities alongside anthropologist Laura Nader (Robinson, 2020, p. xxii). This book argues for a theory of racial capitalism counterposed to what Robinson described as "Eurocentric" Marxism. Simply put, 


\section{THE NEBRASKA EDUCATOR, VOLUME 6}

traditional or "White" Marxism imagines the universal worker as a White male, whereas Black Marxism imagines the universal worker as a Black female, whose body and labor were literally used to reproduce capital in the form of offspring born into enslavement (R. D. G. Kelley, 2017). Concurrent with a variety of anti-apartheid movements - some of which espoused a weak form of multiculturalism that did not center racial oppression-Robinson rejected anti-capitalist efforts that could be "economically radical but racially conservative" (Gordon, 2010). This precise limitation is one that Leonardo (2004) refers to as a failure in Marx's original conceptions of class.

To connect critical Black studies to the earlier section on racial capitalism, it is important to note that Neville Alexander in South Africa and Cedric Robinson in the United States did not use 'racial capitalism' in the same ways. Neville Alexander felt that their use of the term was specific to South Africa and apartheid, while Robinson's brought the conditions of all racialized workers under one umbrella. Both signal that non-racial capitalism is too narrowly centered on economic considerations of capital rather than liberation and reunification for Black peoples who sought repatriation rather than upward (class) mobility (Robinson, 2020).

Applying Black Marxism’s notions of liberation and reunification, and in alignment with the family separation tragedies at the center of Garvey's 'Back to Africa' ethos, the case for reparations for slavery — and the attendant segregation and racism that endure — is self-evident. Coates (2014) provides exhaustive historical detail recounting the "second slavery" that ensued in the South after slaves were ostensibly freed (Coates, 2014, p. 22). These conditions have included housing/zoning discrimination (Rothstein, 2017), employment discrimination, police brutality, and other injustices that leave us divided by the unrepaired racial schism on which our country was literally and figuratively built: slavery. Cotton fragments in our midst-woven 


\section{THE NEBRASKA EDUCATOR, VOLUME 6}

throughout our clothes, shoes, towels, and furniture — all serve to remind us on a daily basis of what enslaved Africans built on stolen Indigenous land, and how the U.S. economy got its start.

To synthesize the forgoing sections, what connects Garvey to Coates to CRT and education is the institution of slavery and its still unattended-to legacy. For this reason, students doing deep, internal race work must endeavor to bridge historical accounts such as GolashBoza's and present-day policy pieces such as Coates's by way of critical Black thinkers such as Garvey and Robinson. Absent these links, some could risk believing that Black Lives Matter and other contemporary movements have arisen spontaneously, from the most recent heinous events, instead of understanding that slavery is the untreated wound at the root of it all. Along the way, and with some basic themes considered, a student might then be ready to contend with more challenging works such as those penned by Malcolm X and W.E.B. Du Bois, as detailed below.

\section{Africans in America}

After learning some basics about Black studies, I was prepared to take on unsettling and innocence-shattering statements such as that the White man is "a piratical opportunist" (X \& Haley, 1964, p. 181) or that "Election expenses today include not only direct bribery but indirect influences" (Du Bois, 1972, p. 3). The Autobiography of Malcolm X and W.E.B. Du Bois's speech on Socialism and the American Negro force us to consider the economic and legislative policies that continue to shackle Black Americans. X describes his existence as the 'mascot' to White people as well as to what it truly means for a man to be self-made, as he was during his prison transformation. Alongside Du Bois's geopolitically inspired lamentation of the American Negro's economic plight, X's treatise on how history has been "whitened” (X \& Haley, 1964, p. 177) extends one's understanding of racism from the individual level to the societal level, as in the work of Scheurich and Young (1997) cited above. "What then is the next step?" asked Du 
THE NEBRASKA EDUCATOR, VOLUME 6

Bois (1972), "It is for American Negroes in increasing numbers and more and more widely to insist upon the legal rights which are already theirs and then to add to that increasingly socialistic form of government an insistence upon the welfare state which denies the further carrying out of industry for the profit of those corporations which monopolize wealth and power?" (p. 4).

Du Bois's piece is as important to critical Black studies for beginners as it is to questioning modern-day fears surrounding socialism, as is Kelley's (1999) overview of Black History's Global Vision. Kelley enlightens our understanding of "the hyphen" in identifiers such as African-American, making possible an illuminated understanding of how global systems of race and imperialism spawned essentialist thinking that manifested in "a bounded national history" for Africans and their descendants around the world. Spanning the years 1883-1950, Kelley's account plumbs the complexities of "citizenship" in countries that do not grant equal rights to people of all races. It is thus that Kelley establishes that, for example, Malcolm X and H. Ford Douglass could not reasonably be seen as traitors to the United States if they were not truly protected as citizens. Not only is a pointed disloyalty understandable in such cases where one's nation has failed him, Douglass averred that, "I can join a foreign enemy and fight against it, without being a traitor, because it treats me as an ALIEN and a STRANGER" (as cited in Kelley, 1999, p. 1049, emphasis in the original). This idea is leveraged to argue that domestic racism results from imperialism (pp. 1053-1054), which is among the tough principles that students must grapple with in contemplating basic critical Black studies before applying this body of knowledge to curriculum and pedagogy.

\section{Afro-Centric Curriculum Studies}

A White student undertaking an introduction to critical Black studies would do well to reflect on the fact that, with this knowledge, we know more now and we also know better. One 


\section{THE NEBRASKA EDUCATOR, VOLUME 6}

cannot unknow (but could simply choose to ignore) the racialized character of our founding. The student therefore could not claim to know the history of the United States of America but rather $a$ history, one of many facets of the "master narrative" (Berry, 2017) composed by the dominant race and class.

Watkins (2009), for instance, guides readers toward releasing ourselves likewise of any conceptions of "the curriculum" which is merely code for the mainstream curriculum movement (p. 321, emphasis added). Watkins enlightens us to six additional orientations to curriculum we might not have considered, each of which is geared toward particular circumstances of Black Americans' experiences of slavery and oppression. These Black curriculum orientations include functionalism, accommodationism, liberalism, reconstructionism, Afrocentrism, and Black Nationalism. It is vital for a student such as myself to read Watkins' account of these isms, lest I be swayed by shallow or ignorant public opinions suggesting that Afrocentrism is discriminatory against White students or that Black Nationalism is radical or on a par with White nationalism.

\section{Reawakening: A Tentative Conclusion}

Given what I have learned about my privileges social position, the history or racial hierarchies in this country, racial capitalism, slavery, and critical race theory, it is not a mystery to me now that the story of Helen and her class on race stayed with me all these years. Looking back, I would not have had the courage or awareness to attempt something like that or even to ask her about it. As for my improv partner's fear of White people, this was yet another tear in the fabric of whatever scenery I had been living in front of and mistaking for real and threedimensional. Proceeding through the vulnerable terrain of my White awakening has revealed a more disturbing landscape that is both fragile and fraught. Studying race, particularly from my White point of view, is work that cannot be accomplished only academically; race work, 


\section{THE NEBRASKA EDUCATOR, VOLUME 6}

especially for people who are unaccustomed to being raced, is uncomfortable personal work that transcends the intellectual.

In the personal inventory that must be done first before teaching others about race, one encounters a stage of learning referred to in therapeutic contexts as the grief of the educationthat moment of crestfallen learning before empowerment takes place. It is the feeling of having eclipsed one's opportunity to act on newfound wisdom because the damage of what has already been lived is so profound. This grief, however, resolves itself — as all grief does — and what rises in its wake is an illumination of conscience, if not action. Perhaps the shame and guilt and demoralization are requisite steps to go through before I can claim to be "using my privilege for good," which is fast becoming yet another privileged trope. Given these conditions, how do we sustain our involvement in that struggle? The answer, Saad (2020) has written to their White audiences, is that "You cannot go back to sleep" (p. 199). The work of waking is never finished. 
THE NEBRASKA EDUCATOR, VOLUME 6

\section{References}

Ardoin, S., \& Martinez, B. (2019). Straddling class in the academy: 26 stories of students, administrators, and faculty from poor and working-class backgrounds and their compelling lessons for higher education policy and practice. Stylus Publishing, LLC.

Baptist, E. E. (2016). The half has never been told: Slavery and the making of American capitalism. Hachette UK.

Bell Jr, D. A. (1980). Brown v. Board of Education and the interest-convergence dilemma. Harvard Law Review, 93(3), 518-533.

Berger, R. (2015). Now I see it, now I don't: Researcher's position and reflexivity in qualitative research. Qualitative Research, 15(2), 219-234.

Berry, T. R. (2017). The intersections of Africana studies and curriculum theory: A counterWestern narrative for social justice. Journal of Curriculum Theorizing, 32(1).

Boswell, E. (2021, April 12). The qualitative imperative: Searching for positionality and reflexivity in mixed methods-grounded theory studies. American Educational Research Association annual meeting.

Casey, Z. A. (2016). A pedagogy of anticapitalist antiracism: Whiteness, neoliberalism, and resistance in education. SUNY Press.

Coates, T.-N. (2014). The case for reparations. The Atlantic, 313(5), 54-71.

Coates, T.-N. (2015). Between the world and me. Spiegel \& Gram.

Cole, T. (2012, March 21). The white-savior industrial complex. The Atlantic. https://www.theatlantic.com/international/archive/2012/03/the-white-savior-industrialcomplex/254843

Crenshaw, K. W. (1990). Mapping the margins: Intersectionality, identity politics, and violence against women of color. Stan. L. Rev., 43, 1241. 


\section{THE NEBRASKA EDUCATOR, VOLUME 6}

Crenshaw, K. W. (1997). Intersectionality and identity politics: Learning from violence against women of color.

Crenshaw, K. W. (2017). On intersectionality: Essential writings. The New Press.

Gee, J. P. (2004). An introduction to discourse analysis: Theory and method. Routledge.

Gee, J. P. (2015). Social linguistics and literacies: Ideology in discourses (Fifth). Routledge.

Goffman, E. (1959). The presentation of self in everyday life. Doubleday.

Golash-Boza, T. M. (2016). The origin of the idea of race. In Race \& racisms: A critical approach (pp. 1-29). Oxford University Press.

Gordon, L. R. (2015). What Fanon said. Fordham University Press.

Grbich, C. (2013). Qualitative data analysis: An introduction (second). Sage.

Hill Collins, P., \& Bilge, S. (2020). Intersectionality. John Wiley \& Sons.

Hoong Sin, C. (2007). Ethnic-matching in qualitative research: Reversing the gaze on "white others" and "white" as "other." Qualitative Research, 7(4), 477-499.

Ignatiev, N. (2009). How the Irish became white. Routledge.

Johnson, W. (2009). Soul by soul. Harvard University Press.

Johnson, W. (2013). River of dark dreams. Harvard University Press.

Johnson, W. (2018, February 20). To remake the world: Slavery, racial capitalism, and justice. Boston Review. http://bostonreview.net/forum/walter-johnson-to-remake-the-world

Jupp, J. C. (2020). First-wave critical White studies. In Z. Casey (Ed.), Critical whiteness studies: Critical understandings in education encyclopedia (pp. 1-13). Brill Publishers.

Kelley, R. D. (1999). "But a local phase of a world problem”: Black history's global vision, 1883-1950. The Journal of American History, 86(3), 1045-1077. 
THE NEBRASKA EDUCATOR, VOLUME 6

Kelley, R. D. G. (2017, January 12). What did Cedric Robinson mean by racial capitalism? Boston Review. http://bostonreview.net/race/robin-d-g-kelley-what-did-cedric-robinsonmean-racial-capitalism

Kendi, I. X. (2019). How to be an antiracist. One world.

Kubota, R. (2020). Confronting epistemological racism, decolonizing scholarly knowledge: Race and gender in applied linguistics. Applied Linguistics, 41(5), 712-732.

Legassick, M., \& Hemson, D. (1976). Foreign investment and the reproduction of racial capitalism in South Africa (Foreign investment in South Africa: A discussion series).

Lensmire, T. J. (2017). White folks: Race and identity in rural America. Routledge.

Lensmire, T. J., McManimon, S., Tierney, J. D., Lee-Nichols, M., Casey, Z., Lensmire, A., \& Davis, B. (2013). McIntosh as synecdoche: How teacher education's focus on White privilege undermines antiracism. Harvard Educational Review, 83(3), 410-431.

Leonardo, Z. (2004). The color of supremacy: Beyond the discourse of 'white privilege.' Educational Philosophy and Theory, 36(2), 137-152.

Milner IV, H. R. (2007). Race, culture, and researcher positionality: Working through dangers seen, unseen, and unforeseen. Educational Researcher, 36(7), 388-400.

Newman, C. (2007). Unguided, on Challengers. Matador.

Pérez Huber, L. (2009). Challenging racist nativist framing: Acknowledging the community cultural wealth of undocumented Chicana college students to reframe the immigration debate. Harvard Educational Review, 79(4), 704-730.

Picower, B. (2009). The unexamined whiteness of teaching: How white teachers maintain and enact dominant racial ideologies. Race Ethnicity and Education, 12(2), 197-215. 


\section{THE NEBRASKA EDUCATOR, VOLUME 6}

Reyes, V. (2018). Three models of transparency in ethnographic research: Naming places, naming people, and sharing data. Ethnography, 19(2), 204-226.

Ribeiro, G. (2011). Why (post)colonialism and (de)coloniality are not enough: A post-imperialist perspective. Postcolonial Studies, 14(3), 285-297.

Robinson, C. J. (2020). Black Marxism: The making of the Black radical tradition. University of North Carolina Press.

Rothstein, R. (2017). The color of law: A forgotten history of how our government segregated America. Liveright Publishing.

Saad, L. F. (2020). Me and White supremacy: Combat racism, change the world, and become a good ancestor. Sourcebooks, Inc.

Saldaña, J. (2018). Researcher, analyze thyself. International Journal of Qualitative Methods, $17(1), 1-7$.

Sarroub, L. K. (2005). All American Yemeni girls: Being Muslim in a public school. University of Pennsylvania Press.

Scheurich, J. J., \& Young, M. D. (1997). Coloring epistemologies: Are our research epistemologies racially biased? Educational Researcher, 26(4), 4-16.

Taylor, K. B., \& Reynolds, D. J. (2019). Dissonance. Chapter 9 in E. S. Abes, S. R. Jones, \& D. L. Stewart (Eds.), Rethinking college student development theory using critical frameworks. Stylus Publishing, LLC, pp. 94-109.

Tippett, K. (2020, April 30). Ocean Vuong-A life worthy of our breath [Radio]. https://onbeing.org/programs/ocean-vuong-a-life-worthy-of-our-breath/

Watkins, W. H. (2009). Black curriculum orientations: A preliminary inquiry. In New Curriculum History (pp. 117-139). Brill Sense. 


\section{THE NEBRASKA EDUCATOR, VOLUME 6}

Wilder, C. S. (2014). Ebony and ivy: Race, slavery, and the troubled history of America's universities. Bloomsbury Publishing USA.

Wilkerson, I. (2020). Caste: The origins of our discontents. Random House. 


\section{Appendix A}

\section{Resource Collections by Topic Area ${ }^{8}$}

\section{Positionality ${ }^{9}$ and Reflexivity_Personal and Institutional}

- Berger, R. (2015). Now I see it, now I don't: Researcher's position and reflexivity in qualitative research. Qualitative Research, 15(2), 219-234.

- Kubota, R. (2020). Confronting epistemological racism, decolonizing scholarly knowledge: Race and gender in applied linguistics. Applied Linguistics, 41(5), 712-732.

- Milner, H. R. (2007). Race, culture, and researcher positionality: Working through dangers seen, unseen, and unforeseen. Educational Researcher, 36(7), 388-400.

- Patel, L. (2015). Decolonizing educational research: From ownership to answerability. Routledge.

- Scheurich, J. J., \& Young, M. D. (1997). Coloring epistemologies: Are our research epistemologies racially biased? Educational Researcher, 26(4), 4-16.

\section{History and Origins of Race/-ism(s) in the United States}

- Golash-Boza, T. M. (2016). The origin of the idea of race. In Race \& racisms: A critical approach (pp. 1-29). Oxford University Press.

- Omi, M., \& Winant, H. (2014). Racial formation in the United States. Routledge.

- Painter, N. I. (2010). The history of White people. WW Norton \& Company.

\footnotetext{
${ }^{8}$ Many of these resources pertain to more than one category, but they are presented here in the topic areas for which they were grouped in the body of the paper.

${ }^{9}$ Sample Positionality Statements, as compiled by the author, are available at: https://bit.ly/PositionalityExemplars
} 
THE NEBRASKA EDUCATOR, VOLUME 6

\section{Critical Race Theory and Critical Whiteness Studies}

- Casey, Z. A. (2016). A pedagogy of anticapitalist antiracism: Whiteness, neoliberalism, and resistance in education. SUNY Press.

- Jupp, J. C. (2020). First-wave critical White studies. In Z. Casey (Ed.), Critical whiteness studies: Critical understandings in education encyclopedia (pp. 1-13). Leiden, The Netherlands: Brill Publishers.

- Jupp, J. C., Berry, T. R., Morales, A., \& Mason, A. M. (2018). What is to be done with curriculum and educational foundations' critical knowledges? Toward critical and decolonizing education sciences. Teaching Education, 29(4), 305-317. https://doi.org/10.1080/10476210.2018.1510484

- Ladson-Billings, G., \& Tate, W. F. (1995). Toward a critical race theory of education. In Critical Race Theory in Education (pp. 10-31). Routledge.

- Picower, B. (2009). The unexamined whiteness of teaching: How white teachers maintain and enact dominant racial ideologies. Race Ethnicity and Education, 12(2), 197-215.

- Taylor, K. B., \& Reynolds, D. J. (2019). Dissonance. In E. S. Abes, S. R. Jones, \& D. L. Stewart (Eds.), Rethinking college student development theory using critical frameworks. Stylus Publishing, LLC.

\section{Africana}

- Coates, T.-N. (2014). The case for reparations. The Atlantic, 313(5), 54-71.

- Du Bois, W. E. B. (1972). Socialism and the American negro: Speech before audience in Great Hall, Madison Wisconsin Memorial Union, April 9, 1960. Folkways Records. 
THE NEBRASKA EDUCATOR, VOLUME 6

- Garvey, M. (1920). "Declaration of the Rights of the Negro Peoples of the World": The Principles of the Universal Negro Improvement Association. Retrieved from http://historymatters.gmu.edu/d/5122/

- Kelley, R. D. (1999). "But a local phase of a world problem": Black history's global vision, 1883-1950. The Journal of American History, 86(3), 1045-1077.

- Robinson, C. J. (2020). Black Marxism: The making of the Black radical tradition. University of North Carolina Press.

- Watkins, W. H. (2009). Black curriculum orientations: A preliminary inquiry. In New Curriculum History (pp. 117-139). Brill Sense.

- X, M., \& Haley, A. (1964). The autobiography of Malcolm X. New York: Ballantine. 
THE NEBRASKA EDUCATOR, VOLUME 6

\section{Appendix B}

\section{Sample Positionality Statements}

\section{Teju Cole's Positionality Statement}

"I write all this from multiple positions. I write as an African, a black man living in America. I am every day subject to the many microaggressions of American racism. I also write this as an American, enjoying the many privileges that the American passport affords and that residence in this country makes possible. I involve myself in this critique of privilege: My own privileges of class, gender, and sexuality are insufficiently examined. My cellphone was likely manufactured by poorly treated workers in a Chinese factory. The coltan in the phone can probably be traced to the conflict-riven Democratic Republic of Congo. I don't fool myself that I am not implicated in these transnational networks of oppressive practices." (Cole, 2012, para. 11)

\section{Johnny Saldaña’s Positionality Statement (Truncated)}

“[...] As an elder gay man of color without a $\mathrm{PhD}$ in theatre — an art form usually perceived by university administrators as a field not as worthy as the hard sciences or other high-incomegenerating disciplines-my "lesser than" statuses have relegated me to the margins for over 40 years as a student and professor in higher education. I have waited so long for equality and social justice. I'll spare you the stories of microaggressions, overt hostility, and discrimination I've experienced, but know that there are some people in the United States who would literally exile or even exterminate me if they could. I've been fighting the good fight for decades and have surprisingly little to show for it. [...]" (Saldaña, 2018, pp. 2-3) 